\title{
Компаративни фразеологизми са полиптозом у средњевисоконемачком периоду
}

\author{
Бранислав Д. Ивановић* \\ Универзитет у Београду, Филолошки фракултет, Катедра за германистику
}

\section{Кључне речи: \\ полиптоза \\ компаративни \\ фразеологизми \\ средњевисоконемачки \\ језик \\ инваријантност \\ примарне \\ фразеологизације \\ фразеолошка фузија \\ фразеолошка супкласа}

\section{Апстракт}

Фразеологија средњевисоконемачке епохе, и данас релативно запостављена област немачке лингвистике, традиционално се бавила истраживањима пословица, крилатица и геминатних фразеологизама као најфреквентнијих фразеолошких супкласа у корпусу текстова из наведеног периода. Остале супкласе за историјску фразеологију постале су интересантне тек током последње деценије. Иако се истраживања у овој области интензивирају, системска питања и даље нису решена на задовољавајући начин. Једно од таквих несумњиво је и питање синхронијског описа и утврђивања јасних обележја појединачних фразеолошких супкласа с обзиром на изражену конвергенцију међу њима у минулим епохама. Лингвистички заснован и јасан опис појединачних супкласа из средњевисоконемачке епохе не доприноси искључиво бољем синхронијском увиду у системска обележја фразеолексикона у средњевисоконемачком периоду, већ уједно представља и основ за лакшу идентификацију фразеологизама у текстовима ове епохе, јаснији увид у међуоднос различитих супкласа, али и темељ за утврђивање свих дијахронијских промена у млађим језичким епохама, које су профилисале стање у фразеолексикону савременог немачког језика. У раду се утврђују системска формална и семантичка обележја малобројне супкласе компаративних фразеологизама са полиптозом, обележја полиптозе код наведене супкласе, али и феномен фразеолошке фузије специфичан за ове фразеологизме. (примьено: 17. августа 2021; прихваћено: 24. септембра 2021) www.anali.fil.bg.ac.rs

АНАЛИ ФИЛОЛОШКОГ ФАКУЛТЕТА

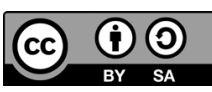

Филолошки факултет Катедра за германистику Студентски трг 3 11000 Београд, Србија branislav.ivanovic@fil.bg.ac.rs 


\section{1. Увод}

Системска проучавања фразеологије средњевисоконемачког језика, периода у историји немачког језика од 1050. до 1350. године (у даљем тексту срвн.), традиционално су ретка тако да се може рећи да је ова област германистичке лингвистике и данас једна од најмање проучених. Садашње стање резултат је готово искључиве усмерености класичне историје језика на фонетику, морфологију и синтаксу наведене епохе уз истовремено ограничавање историјске фразеологије на проучавања геминатних фразеологизама (нем. Paarformel/Zwillingsformel, f), пословица и крилатица (Burger, 2012: 1), оних фразеолошких супкласа, које се у корпусу срвн. текстова чешће јављају и које су за период од XI до XIV века несумњиво од већег културолошког значаја. Иако се током последње деценије тежиште у проучавањима фразеологије срвн. епохе помера пре свега на различите типове идиома, али и колокација (Burger, 2012: $7,13)$, истраживања још увек не показују континуитет у сагледавању одређеног фразеолошког феномена са различитих аспеката и не нуде целовитију слику о фразеологијаи овог периода.

Једно од централних системских питања фразеологије срвн. периода још увек није решено на адекватан начин, а то су што је могуће прецизнија дефиниција и јасно одређење појединачних фразеолошких супкласа у срвн. епохи, и то на основу установљених формалних и семантичких обележја за сваку од њих у овом периоду, а који би били резултат анализе различитих фразеологизама из срвн. текстуалног корпуса или лексикографских извора. Историјска фразеологија је у овом погледу најчешће преузимала дефиниције одређене супкласе, којима се оперише у фразеологији савременог немачког језика, занемарујући при томе чињеницу да сваки језички ниво неминовно бива захваћен дијахронијским променама и да обележја појединих супкласа у срвн. епохи у поређењу са стањем у савременом језику често могу да буду само делимично идентична.

Опис формалних обележја појединачних фразеолошких супкласа у срвн. периоду утолико је значајнији уколико се у виду има једна од основних тенденција фразеолексикона у минулим језичким периодима, а то је да су односи између две или више различитих фразеолошких супкласа у њима по правилу много конвергентнијег карактера него што је то случај у савременом немачком језику (Ивановић, 2021: 364, 375). Под овим треба подразумевати чињеницу да две или више различитих супкласа често показују већи број заједничких него дистинктивних формалних обележја у поређењу са данашњим немачким језиком као и да се дистинктивна обележја једне супкласе јављају и код друге/других због чега је сваки конкретан срвн. фразеологизам често много теже сврстати у тачно одређену супкласу.

\section{2. Значај познавања формалних обележја срвн. фразеолошких} супкласа

Детаљно познавање формалних обележја појединачних фразеолошких супкласа у срвн. епохи релевантно је и за синхронијску и за дијахронијску 
перспективу. Синхронијски се описом посебних супкласа стиче много јаснији и свеобухватнији увид у системске закономерности и трендове специфичне за фразеолексикон срвн. језика, сигурнија идентификација фразеологизама у текстовима из наведеног периода, али и много егзактније сазнање о процесима примарне фразеологизације. Познавање обележја фразеолошких супкласа из старије језичке епохе у дијахронијском погледу представља једино научно утемељено полазиште за праћење промена на свим нивоима у структури фразеолошког форматива у млађим језичким епохама, захваљујући којима се профилисало данашње стање у фразеолексикону немачког језика.

\section{3. Циљ рада и корпус}

Циљ рада је да сена мањем броју посведочених примера синхронијски опишу обележја структурно инваријантне супкласе компаративних фразеологизама са полиптозом и да се установе сличности и разлике са прототипичним срвн. компаративним фразеологизмима, али и са оним фразеолошким супклама у наведеној језичкој епохи између којих са полиптотоним компаративним фразеологизмима постоје изражени процеси фразеолошке фузије.

Фразеологизми са контекстуализацијом лематизовани су под одредницом danne/denne у Mittelhochdeutsches Wörterbuch. Band I A-L $L^{1}$ aymopa Георга Фридриха Бенекеа (Georg Friedrich Benecke), Вилхелма Милера (Wilhelm Müller) и Фридриха Царнкеа (Friedrich Zarncke).

\section{4. Дефиниција и прототипична обележја срвн. компаративних фра- зеологизама.}

Компаративни фразеологизми представљају компонентски релативно отворену, односно компонентски мање стабилну и синтаксички врло разнородну супкласу компонентних идиома, која се одликује поредбеном синтагматском структуром, а тиме и бищентричношћу синтагматског низа с обзиром на то да се састоје од два члана: comparanduma, који је и семантичка база (нем. semantische Basis) целог фразеологизма јер унутар истог показује своје ендосемемско (лексикализовано, транспарентно, ванфразеолошко) значење, $и$ comparatuma, другог члана поредбене структуре. Наведени чланови компаративног фразеологизма се доводе у одређену везу на основу заједничког, често претпостављеног и не нужно каузално утемељеног заједничког обележја, tertium-a comparationis-a. У зависности од морфолошких обележја семантичке базе, али и врсте поређења, синтаксичка веза између два наведена фразеолошка пола се у срвн. периоду реализује еквативним или компаративним партикулама als, alse, alsam, sam, dann(e), denne, so и wie, субјунктивним елементима als и sam или, што је и најређе, субјунктором als ob. Функција поређења код ових фразеологизама је двострука и састоји се у конкретизацији и додатном објашњењу comparandum-a, односно семантичке базе, али и њеној интензификацији 
(Burger/Jaksche, 1973: 49; Pilz, 1981: 84; Burger et al., 1982: 35-36; Fleischer, 1997: 104-105). Прототипични компаративни фразеологизми у срвн. периоду се квалификују као сликовите и врло експресивне лексикализоване структуре.

Таксативно се прототипична формална обележја ове супкласе у срвн. епохи могу представити на следећи начин (Ивановић, 2021: 368-375):

- уочљива бицентричност: weinen als ein kint, brimmen als ein eberswîn, а изузетно ретко моноцентричност синтагматског низа, нпр. [...] sam die blinden, [...] als al die boume trüegen golt

- уочљива компонентска хетероморфност

- хетерогеност синтаксичке структуре - инфинитивне, адјективске, номиналне и адвербијалне фразе: limmen als ein bër, swarz als eines bëren zagel, weicher danne ein blî, eine stimme als ein donnerslac, niender als ein bône

- могућа флуктуација синтаксичке форме: zürnen/zornic als ein bër

- Од срвн. компаративних партикула јављају се искључиво dan(ne) и denn(e), рецентне срвн. компаративне партикуле wan(ne), wenne, newan, et, eht не јављају се у лексикализованим и хабитуалним поређењима.

- Други члан компаративног фразеологизма, comparatum, по правилу је репрезентован номиналном фразом, најчешће минималном, а peђе са атрибутима, уз могуће компонентске алтернације: swære als ein bërc/brant/alsam ein blî, gân als ein gesmirwter wagen.

- Могућа је инверзија чланова поређења са редоследом поредбена nартикула - comparatum - comparandum: als ein donner(slac) (er)hëllen.

- Могуће су алитерација (нем. Stabreim, m), хомеотелеутон (нем. Homoioteleuton, n) и figura etymologica (нем. etymologische Figur): glat als glas, rôt als ein bluot, glüejen als ein gluot ${ }^{2}$.

На основу прототипичних обележја срвн. компаративних фразеологизама могу се установити сличности и разлике, које у истој епохи показује супкласа компаративних фразеологизама са полиптозом. На основу консултованог лексикографског извора у њу спадају:

schœner danne schœen

be33er denne guot

wirs denne wê $\mathrm{n}$

mêre dan ze vil.

\section{5. Опште одређење полиптозе}

Већ се и на основу наведених примера може уочити суштина полиптозе или полиптотона (нем. Polyptosis, f, Polyptoton, $n$ ). Реч је о веома старом фено-

2 Ово је пример за етимолошку фигуру у ширем смислу с обзиром на то да се иста у свом прототипичном облику јавља као инфинитивна фраза у којој је именица као зависни елемент у чистом акузативу (Simeon, 1969: 323). 
мену, познатом у индоевропским језицима ${ }^{3}$, и то у различитим фазама њиховог развоја, који је најчешће коришћен као стилска фигура у књижевности, али се може посматрати и као чисто језички механизам.

Полиптоза се заснива на редупликацији, односно рекурентности једне речи у слободним синтагмама и реченицама, односно једне компоненте у фразеологији, при чему је предуслов да се у синтагматском низу јави у различитим флективним облицима (Simeon, 1969a: 83; Bußmann, 1990: 593; Schweikle, 2000: 537; Wilpert, 2001: 623). Из дефиниције јасно проистиче да је полиптоза везана искључиво за променљиве врсте речи и у том погледу се у немачком језику као прототипичне могу разликовати именичка, придевска и глаголска, а у ограниченом обиму и прилошка, па чак и детерминативска полиптоза. Она може бити уникатегоријална, када долази до промене искључиво једног категоријалног обележја (падежа, степена код придева или прилога, лица или времена код глагола), али и поликатегоријална, када се истовремено уочавају промене бар два категоријална обележја (нпр. падежа и броја код именичке полиптозе), нпр.:

старовисоконемачки: bên zi bêna, bluot zi bluota (Zweiter Merseburger Zauberspruch)

срвн. aller nœte not

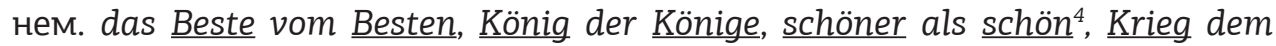
Kriege $^{5}$

Seine Meinung sagt er von seinem Jahrhundert, er sagt sie, nochmals sagt sie laut,

hat sie gesagt und geht ab. (Goethe \& Schiller: Xenien, 185)

Wenn mancher Mann wüsste, wer mancher Mann wär', gäb` mancher Mann

manchem Mann manchmal mehr Ehr`.6

3 Уп. примере полиптозе у латинском, нпр. чувена крилатица из Плаутове комедије Asinaria (Mazapци):

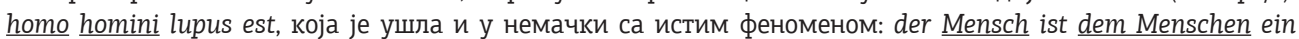
Wolf. Полиптоза се у енглеском језику уочава нпр. код следећих структура библијског порекла The Song of the Songs, judge not that ye be not judged, а заступљена је и у српском језику, нпр. све горе од горег, боре

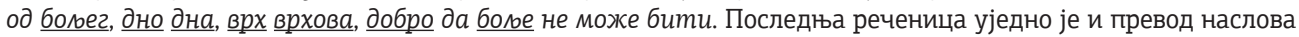
америчког филма As good as it gets Џејмса Лоренса Брукса (Jamse Lawrence Brooks) из 1997. године.

4 Schöner als schön назив је и музичке композиције аустријског глумца, композитора и текстописца Александера М. Хелмера (Alexander M. Helmer).

5 Ово је део наслова књиге пацифисте Ернста Фридриха (Ernst Friedrich) објављене 1924. године. У књизи се говори о катастрофалним последицама Првог светског рата, а њен пун наслов гласи Krieg dem Kriege!Guerre à la Guerre! War against War! Oorlog aan den Oorlog!.

6 Овај натпис се налази у Свидницкој пивници (пољ. Piwnica Świdnicka, нем. Schweidnitzer Keller) у Вроцлаву, једној од најпознатијих туристичких атракција овог града. У наведеном примеру полиптоза је комбинована са паронимијом: mancher - manchem - manchmal. 
Полиптоза у формалном погледу највише личи на редупликацију (нем. Reduplikation, f) и већ споменуту етимолошку фигуру. Редупликација се у односу на полиптозу може одредити као терминолошки хипероним с обзиром на то да је шири и општији појам од полиптозе јер може да подразумева $и$ понављање истих, али и сличних јединица испод нивоа речи, нпр. истог или сличног гласа, слога, морфеме или субморфеме, као и понављање непроменљивих врста речи, што је код полиптозе искључено. Уколико се говори о редупликацији код променљивих врста речи, она не подразумева нужно и различите флективне облике. Додатно, редупликација је у старом језичком слоју фунгирала и као граматичко средство јер се помоћу ње у индоевропском глаголском систему градио презент свршених глагола, а удружена са апофонијом служила је и за грађење прајезичког перфекта (Krahe, 1969: 55; Костић-Томовић/Ивановић, 2019 : 249). Оба феномена морфолошки су, дакле, релевантна: редупликација јер је у одређеној фази у развоју језика била функционализована у флексији, а полиптоза јер се заснива на алтернацији категоријалних обележја специфичних за сваку од променљивих врста речи које су у њеној основи, при чему се претпоставља корелативан однос између различитих алтернација и развијености флексије. Развијенији полиморфизам свакако треба очекивати код оних индоевропских језика са развијенијом флексијом, а то су свакако флективно-синтетички.

Осим из морфолошке, редупликација и полиптоза се могу дистингвирати и из творбене визуре јер се обе могу квалификовати и као специфични творбени модели. Резултат различитих механизама редупликације, у прошлости много чешћег творбеног модела, а данас у западно- $и$ северногерманским језицима свакако маргиналнијег карактера, јесу различити подтипови новонасталих лексема (Kostić-Tomović, 2013: 93-94; Bilandžija, 2017: 178-181), док као резултат полиптозе под одређеним предусловима не настају нове лексеме, већ искључиво нови фразеологизми.

За фразеологију, али и германистичку лингвистику уопште, од примарног значаја је хабитуална полиптоза као устаљени језички механизам за настанак нових фразеолошких структура. Хабитуална полиптоза показује синтаксичку затвореност и њу треба разликовати од оказионалне поетске полиптозе, која је по својој природи отворенија и слободнија и за коју је као за посебну стилску фигуру превасходно заинтересована наука о књижевности, иако се оба типа у основи заснивају на идентичном језичком модалитету. Differentia specifica између хабитуалне и поетске полиптозе у фразеологији успоставља се на основу чињенице да као резултат хабитуалне увек настаје одређена, макар и ограничена серија лексикализованих фразеологизама, док код поетске то није случај. Резултат поетске полиптозе увек треба посматрати као збир индивидуалних, дакле различитих и јединствених естетских решења у књижевном тексту, која задовољавају основну премису овог језичког механизма, а то је да се лексички редупликат мора јавити у различитим флективним облицима.

И полиптози и етимолошкој фигури заједничко је то што се и потоња може сматрати врло специфичним фразеодериватолошким моделом с обзиром на то 
да као резултат етимолошке фигуре настају малобројни компонентни идиоми, нпр. срвн. glüejen als ein gluot, нем. seinen Kampf kämpfen, seinen Gang gehen. Од исте се полиптоза разликује по томе што никада не подразумева понављање две различите речи, које потичу од истог корена и у уочљивом су етимолошкотворбеном контигвитету, а додатно дистинктивно обележје је свакако и израженији полиморфизам код полиптозе.

\section{6. Обележја срвн. компаративних фразеологизама са полиптозом}

Ови се фразеологизми дефинишу као псеудохомоморфне бицентричне структуре јер оба члана поређења, и comparandum и comparatum, представљају редупликате у различитом флективном облику. У поређењу са прототипичним компаративним фразеологизмима из срвн. епохе, нису морфосинтаксички хетерогени и не показују морфосинтаксичку флуктуацију с обзиром на то да се јављају искључиво у облику адјективске или адвербијалне фразе: schœner danne schœn, односно wirs denne wê. Синтаксички посматрано, нуклеус увек има облик компаратива, а његова допуна увек је у облику dan(ne)/denne-фразе са позитивом истог придева или прилога. У оквиру допуне могућ је и облик ексиесива (zе + vil). Облик компаратива синтаксичког нуклеуса, а истовремено и семантичке базе целе коокуренције, код ове подгрупе фразеологизама искључује еквативне партикуле.

\section{1. Специфичности полиптозе код срвн. компаративних фразеологизама}

Полиптоза код ове групе фразеологизама хабитуалног је карактера и показује одређене специфичности. За разлику од хабитуалне адјацентне полиптозе, која подразумева директну контактну позицију између редупликата и у срвн. епохи се због могуће пре-, али и постпонираности генитивског атрибута код именичког типа јавља према два позиционо варијабилна модела

$$
\begin{aligned}
& \boldsymbol{X}_{\text {именицау генитиву сингулара/плурала }}+\boldsymbol{X}_{\text {именица у номинативу сингулара }} \\
& \boldsymbol{X}_{\text {именицау номинативу сингулара }}+\boldsymbol{X}_{\text {именица у генитиву сингулара/плурала, }}
\end{aligned}
$$

придевска/прилошка полиптоза је код ове супкласе срвн. фразеологизама по својој природи увек дистантна јер се између адјективских или адвербијалних редупликата неизоставно мора јавити поредбена партикула $\operatorname{dan}(n е)$ или denпе како би се реализовало поређење.

Друго специфично обележје полиптозе код ове групе фразеологизама је то да је увек реч о уникатегоријалном типу овог језичког механизма јер долази до промене искључиво једног морфолошког обележја специфичног за врсту речи из које потиче компонента. У овом случају у питању је категорија степена. Код отворене, нефразеолошке и поетске полиптозе придевског типа у срвн. књижевности могућа је промена и више категоријалних обележја, што је изазвано различитим синтаксичким функцијама придева, нпр. истовремена разлика у 
категорији степена праћена разликом између флектираног и нефлектираног облика придева:

\section{[...] sine kundes nicht bescheiden baz der guoten [...] (Das Nibelungenlied)}

Треће уочљиво обележје полиптозе код ове фразеолошке супкласе у срвн. епохи је то да се код њих могу јавити два морфолошка подтипа ове појаве. Први је код анализираних примера ређи, а реч је о чистој или транспарентној полиптози, која се уочава код фразеологизма schœner danne schœn с обзиром на то да наведени придев у срвн. периоду различите степене гради на системски начин. Други тип је чешћи. Реч је о суплетивној или затамњеној полиптози с обзиром на то да придев guot и прилози wê и vil показују дефективност парадигме:

\section{be33er denne guot}

wirs denne wê

mêre dan ze vil.

Последње специфично обележје полиптозе код ових срвн. фразеологизама је њен инверзни карактер, а под овим се подразумева да се у линеарном низу фразеологизма без изузетка на првом месту јавља компонента у компаративу као секундарном морфолошком облику, а на другом у позитиву као основном и примарном морфолошком облику придева или прилога.

\section{2. Специфичност компаративних партикула}

Иако Бенеке, Милер и Царнке у свом речнику под одредницом danne/denne наводе податак да се поредбена партикула у облику denne у срвн. епохи битно ређе јавља, а да је много фреквентнији облик danne, код наведених примера је управо доминантан први. Апокопирана форма dan је најређа. На основу малог броја примера се не може закључити да ли фонетско окружење или морфолошки подтип полиптозе имају одређеног значаја при дистрибуцији различитих облика поредбене партикуле. Алтернације у облицима поредбене партикуле треба превасходно тумачити као заједничко формално обележје свих компаративних фразеологизама у срвн. језику, и оних прототипичних, али и оних са полиптозом.

\section{3. Примарна фразеологизација}

Код прототипичних компаративних фразеологизама примарна фразеологизација настаје процесима експанзије тако што се семантичка база фразеологизма, компонента са транспарентним значењем у новонасталој фразеолошкој структури, доводи у поредбену, а тиме и логичко-семантичку везу са другим чланом на основу tertium-a comparationis-a. Семантичка база се проширује чланом којим се пореди, comparatum-ом, који често садржи и примарну фразео- 
лошку слику због чега се може посматрати и као специфичан фразеолошки фокус, тачније онај део целе структуре који прототипичним компаративним фразеологизмима даје експресивност. На овај начин настаје синтагматски фразеолошки низ са поредбеном структуром, односно прототипични компаративни фразеологизам. У семантичком погледу се функција comparatum-a састоји у квалификацији семантичке базе, њеној допунској експликацији, али и њеној интензификацији (Burger/Jaksche, 1973: 49; Pilz, 1981: 84; Burger et al., 1982: 35-36; Мршевић-Радовић, 1987: 42; Fleischer, 1997: 104-105).

С обзиром на то да семантичка база код прототипичних компаративних фразеологизама потиче од различитих врста речи (придев у позитиву/компаративу, глагол, именица), али и да се фразеолошки фокус морфосинтаксички различито реализује (минимална номинална фраза, номинална фраза са различитим атрибутима), примарна фразеологизација код прототипичних компаративних фразеологизама резултује морфосинтаксички изразито хетерогеним структурама.

Иако их везује једно заједничко обележје, а то је експанзија семантичке базе comparatum-ом, процес примарне фразеологизације код срвн. полиптотоних компаративних фразеологизама битно је другачији. Он је потпуно формамизован и подразумева постојање једног инваријантног синтаксичког модела, у овом случају је то:

$$
\boldsymbol{X}_{\text {компаратив }}-\operatorname{dan}\left(\text { ne)/denne }-[z e] \boldsymbol{X}_{\text {позитив }}\right.
$$

који се попуњава искључиво једном придевском или прилошком компонентом. Процес примарне фразеологизације заснован је на својеврсној опозицији: инваријантни синтаксички модел, нека врста непроменљиве и a priori задате апстрактне формуле, попуњава се варијабилним придевским или прилошким компонентама. На овај начин настају серије структурно потпуно унисоних компаративних фразеологизама:

\section{schœener danne schœen}

be33er denne guot

wirs denne wê

mêre dan ze vil.

Поред постојања инваријантног синтаксичког модела, примарна фразеологизација код овог подскупа праћена је и постојањем инваријантног семантичког модела, који се дефинише искључиво као интензификација семантичке базе, а која је израженија код присутног ексцесива (ze + позитив). За разлику од прототипичних срвн. компаративних фразеологизама, comparatum код полиптотоних нема функцију њене конкретизације. На овај начин се полиптоза искључиво на семантичком, не и на формалном нивоу приближава асцендентној градацији (Ковачевић, 2019: 230-232). 
Општи семантички предуслов за настанак оваквих фразеологизама је тај да придев или прилог имају могућност степеновања, што је код прилога могуће у веома ограниченом обиму, из чега се закључује да би се анализом корпуса срвн. текстова нашло више придевских фразеологизама овог типа.

По процесу примарне фразеологизације срвн. компаративни фразеологизми са полиптозом потпуно су удаљени од оних прототипичних у истој епохи, а у основи су идентични са малобројном супкласом моделираних фразеологизама (нем. Modellbildung, $f$, modellierte Bildung). Заједничка обележја са моделираним фразеологизмима су им инваријантни синтаксички и семантички модели, нпр.:

von houbet unz an33 ende

von tage ze tage.

Истраживања су показала да постојање инваријантног синтаксичког или семантичког модела и серије фразеологизама стоје у специфичном односу: иако компонентска варијабилност уз задовољење семантичког момента у смислу логичности значења целе структуре у теоријском смислу подразумева веома велики број могућности, серије су по правилу врло ограничене у квантитативном смислу, а то значи да је број овако насталих лексикализованих структура у основи мали (Stepanova/Černyševa, 1975: 233), што је највероватније и разлог да се под одредницом danne/denne у нашем лексикографском извору нађе невелики број компаративних фразеологизама са полиптозом. Додатно, потпуна синтаксичка и семантичка моделираност, праћене апсолутном варијабилношћу компонената, које у основи задржавају своје транспарентно и препознатљиво значење, овакве коокуренције сврставају на периферију фразеолексикона, а класична немачка фразеологија им ни не признаје статус фразеологизма (Stepanova/Černyševa, 1975: 233; Fleischer, 1997: 130-134), што је разлог и за то да се моделиране структуре, па тиме и срвн. компаративни фразеологизми са полиптозом, у ограниченом обиму могу наћи у општем речнику срвн. језика, али не и у фразеолошком речнику ове епохе. Из наведеног треба закључити да полиптотони компаративни фразеологизми у срвн. епохи представљају највероватније малобројну фразеолошку супкласу.

6.4. Компонентски састав срвн. компаративних фразеологизама са полиптозом

Специфичност примарне фразеологизације и полиптоза као језички механизам у њеној основи условљавају и специфичности компонентског састава код ове групе. Посматрамо ли их међусобно, они су компонентски потпуно варијабилни, али је сваки за себе компонентски апсолутно стабилан. По овоме се разликују од прототипичних компаративних фразеологизама у истој епохи, који се одликују компонентском нестабилношћу и могућим алтернацијама, посебно у оквиру comparatum-а. Резултат компонентске нестабилности и алтернација увек су дублетни облици истог фразеологизма, што је код срвн. полиптотоних компаративних као могућност искључено. 
У формалном погледу се по компонентском саставу приближавају адјективским или адвербијалним геминатним фразеологизмима, и то само по псеудохомоморфности компонената јер за разлику од геминатних, код којих су присутне две различите компоненте из исте врсте речи (праве хомоморфне компоненте), код полиптозе се ради о једној, али редупликованој, и то у различитим флективним облицима, што овим структурама даје таутолошки карактер. Додатну разлику такође треба видети у томе што се код компаративних фразеологизама као релациона компонента јавља искључиво поредбена партикула са могућим алтернацијама облика, а не конјунктори као код геминатних.

Сличност компонентског састава са моделираним фразеологизмима (von tage ze tage) треба видети у могућој, али факултативној редупликацији исте компоненте, која је код полиптозе, а тиме и код срвн. компаративних фразеологизама обавезна.

За разлику од прототипичних срвн. компаративних фразеологизама, код полиптотоних је искључен фразеолошки фокус те у њиховој основи не постоји фразеолошка слика.

\section{5. Позициона стабилност компонената}

Ова група се одликује и апсолутном позиционом стабилношћу, која је условљена инваријантношћу модела, што је иначе ређе обележје фразеологизама у срвн. периоду с обзиром на то да се позициона стабилност компонената, односно њихова иреверзибилност код различитих фразеолошких супкласа у највећој мери успоставља тек након срвн. епохе (Burger/Linke, 1985: 2023). По обележју иреверзибилности веома су сродни моделираним фразеологизмима, а истовремено се разликују од прототипичних инверзних срвн. компаративних фразеологизама, код којих се comparatum са поредбеном партикулом може наћи испред comparandum-a, нпр. als ein vogel vrî, али и од великог броја геминатних у овој епохи, нпр. bërc unde tal/tal unde bërc.

\section{6. Специфичност синтаксичке функције}

Уколико је компонента придевског порекла, срвн. компаративни фразеологизми са полиптозом представљају једину подгрупу компаративних фразеологизама, која се може јавити у функцији атрибута у левом пољу номиналне фразе, и то са флектираним обликом последњег члана фразеологизма:

Sist schœener danne ein schœne wîp.

6.7. Полиптотони срвн. компаративни фразеологизми као фузиона супкласа

На основу описаних системских обележја посведочених примера може се рећи да срвн. компаративни фразеологизми са полиптозом представљају посебну супкласу, коју карактерише веома изражена фразеолошка фузија, а то значи да показују специфично укрштање различитих формалних и семантичких обележја, која су им инхерентна, а истовремено су диференцијална или специфич- 
на и за остале фразеолошке супкласе. За прототипичне компаративне фразеологизме их на формалном пллану везује поредбена структура синтагматског низа, а на семантичком интензификација значења, али не и конкретизација семантичке базе. По процесу примарне фразеологизације на основу инваријантног синтаксичког, али и семантичког модела и по свом серијском карактеру идентични су са моделираним фразеологизмима у ужем и ширем смислу, а по псеудохомоморфности и синтаксичкој унисоности се приближавају геминатним фразеологизмима.

\section{7. Закључак}

Компаративни фразеологизми са полиптозом у срвн. епохи представљају малобројну и посебну подгурпу компаративних фразеологизама, која се у структурном смислу састоји од морфосинтаксички једноставних бицентричних коокуренција са поредбеном структуром и алтернацијом компаратива и позитива рекурентне компоненте. Ови фразеологизми се јављају искључиво у облику адјективске или адвербијалне фразе, а њихово основно системско обележје је фразеолошка фузија с обзиром на то да у себи уједињују доминантна обележја различитих фразеолошких супкласа: процес примарне фразеологизације и њихов серијски карактер идентични су као код моделираних фразеологизама, док су им поређење и интензификација семантичке базе заједничка обележја са прототипичним компаративним фразеологизмима. Од прототипичних компаративних фразеологизама удаљени су по псеудохомоморфности, једноставној синтаксичкој структури и моделираности, чиме се приближавају супкласи адјективских и адвербијалних геминатних фразеологизама.

Обележја полиптозе код ове супкласе јасно су уочљива. Реч је о дистантном и инверзном уникатегоријалном типу, који се морфолошки двојако репрезентује: као чиста и као суплетивна полиптоза.

\section{Литература}

Ивановић, Б. (2021). Формална обележја компаративних фразеологизама у средњевисоконемачком језику. Филолог, XII(23), 363-379.

[Ivanović, B. (2021). Formalna obeležja komparativnih frazeologizama u srednjevisokonemačkom jeziku. Filolog, XII(23), 363-379]

Ковачевић, М. (2019). Интерференција кумулације, корекције и фигуре порицања и тврђења са градацијом. У А. Крстановић и љ. Аћимовић (ур.), Компаратистичка истраживана. Зборник филолошких прилога у част проф. др Ради Станаревић (стр. 227-247). Бања Лука: Филолошки факултет.

[Kovačević, M. (2019). Interferencija kumulacije, korekcije i figure poricanja i tvrđenja sa gradacijom. U A. Krstanović i Lj. Aćimović (ur.), Komparatistička istraživanja. Zbornik filoloških priloga u čast prof. dr Radi Stanarević (str. 227-247). Banja Luka: Filološki fakultet]

Костић-Томовић, Ј., Ивановић, Б. (2019). Унутрашња редупликација у немачком језику између језичке историје и актуелних тенденција. У А. Крстановић и 
Љ. Аћимовић (ур.), Компаратистичка истраживаюа. Зборник филолошких прилога у част проф. др Ради Станаревић (стр. 248-259). Бања Лука: Филолошки факултет.

[Kostić-Tomović, J., Ivanović, B. (2019). Unutrašnja reduplikacija u nemačkom jeziku između jezičke istorije i aktuelnih tendencija. U A. Krstanović i Lj. Aćimović (ur.), Komparatistička istraživanja. Zbornik filoloških priloga u čast prof. dr Radi Stanarević (str. 248-259). Banja Luka: Filološki fakultet]

Мршевић-Радовић, Д. (1987). Фразеолошке глаголско-именичке синтагме у савременом српскохрватском језику. Београд: Филолошки факултет.

[Mršević-Radović, D. (1987). Frazeološke glagolsko-imeničke sintagme u savremenom srpskohrvatskom jeziku. Beograd: Filološki fakultet]

Benecke, G. F., Müller, W., Zarncke, F. (1990). Mittelhochdeutsches Wörterbuch. Band I A-L. Stuttgart: S. HIRZEL Verlagsgesellschaft.

Bilandžija, S. (2017). Slaganje u skandinavskim jezicima - prototip i periferija. Beograd: FOCUS - Forum za interkulturnu komunikaciju.

Burger, H. (2012). Alte und neue Fragen, alte und neue Methoden der historischen

Phraseologie. In N. Filatkina et al. (Eds.), Aspekte der historischen Phraseologie und

Phraseographie (pp. 1-20). Heidelberg: Universitätsverlag WINTER.

Burger, H., Buhofer, A., Sialm, A. (1982). Handbuch der Phraseologie. Berlin: Walter de Gruyter.

Burger, H., Jaksche, H. (1973). Idiomatik des Deutschen. Tübingen: Max Nimeyer Verlag Burger, H., Linke, A. Historische Phraseologie. In W. Besch, O. Reichmann \& S. Sonderegger

(Eds.), Sprachgeschichte. Ein Handbuch zur Geschichte der deutschen Sprache und ihrer Erforschung. Zweiter Halbband (pp. 2018-2026). Berlin: Walter de Gruyter.

Bußmann, H. (1990). Lexikon der Sprachwissenschaft. Stuttgart: Alfred Kröner Verlag. Fleischer, W. (1997). Phraseologie der deutschen Gegenwartssprache. Tübingen: Max Nimeyer Verlag.

Kostić-Tomović, J. (2013). Tvorba reči u savremenom nemačkom jeziku. Beograd: FOKUS

- Forum za interkulturnu komunikaciju.

Krahe, H. (1969). Indogermanische Sprachwissenschaft II. Formenlehre. Berlin: Walter de Gruyter \& Co.

Pilz, K. D. (1981). Phraseologie. Stuttgart: J. B. Metzlersche Verlagsbuchhandlung.

Simeon, R. (1969). Enciklopedijski rječnik lingvističkih naziva A-O. Zagreb: Matica hrvatska.

Simeon, R. (1969a). Enciklopedijski rječnik lingvističkih naziva P-Ž. Zagreb: Matica hrvatska.

Schweikle, G. (2000). Polyptoton. In H. Glück (Ed.), Metzler Lexikon Sprache (p. 537). Stuttgart-Weimar: Verlag J. B. Metzler.

Stepanova, M., Černyševa, I. (1975). Lexikologie der deutschen Gegenwartssprache. Moskau: Verlag „Hochschule“.

Wilpert, G. von (2001). Sachwörterbuch der Literatur. Stuttgart: Alfred Kröner Verlag. 


\section{Branislav D. Ivanović}

Zusammenfassung

\section{POLYPTOTON BEI DEN MITTELHOCHDEUTSCHEN KOMPARATIVEN PHRASEOLOGISMEN}

Mittelhochdeutsche polyptotone komparative Phraseologismen stellen eine nicht so zahlreiche phraseologische Subklasse der morphosyntaktisch einfachen bizentrischen Kookurrenzen dar, deren distinktive strukturelle Merkmale Komparation und Rekurrenz der Komponente in unterschiedlichen Flexionsformen sind. Die einzigen Ausdrucksformen dieser Phraseologismen sind Adjektival- und Adverbialphrasen. Diese Subklasse zeichnet sich durch eine ausgeprägte phraseologische Fusion aus, zumal sie prototypische Merkmale von diversen phraseologischen Subklassen aufweist. Der Prozess der primären Phraseologisierung beruht auf dem invarianten syntaktischsemantischen Modell, was für Modellbildungen als typisch zu gelten hat. Durch ihre komparative syntaktische Struktur und durch die Bedeutungsverstärkung ähneln diese Phraseologismen den prototypischen komparativen in der mittelhochdeutschen Sprache und dank den pseudohomomorphen Komponenten in der Formativstruktur und ihrem seriellen Charakter können sie mit Paarformeln gleichgesetzt werden. Das unikategoriale Polyptoton wiest bei dieser mittelhochdeutschen Subklase Distanzstellung der reduplizierten Komponente sowie zwei morphologische Varianten: die transparente und die suppletive.

\section{Schlüsselwörter:}

Polyptoton, komparative Phraseologismen, Mittelhochdeutsch, Invarianz der primären Phraseologisierung, phraseologische Fusion, phraseologische Subklasse

\section{Summary}

\section{COMPARATIVE PHRASEOLOGISMS WITH POLYPTOTON IN MIDDLE HIGH GERMAN}

Middle High German does not have too many comparative phraseologisms that contain polyptoton. Polyptoton is a linguistic mechanism in which words are repeated in a different inflection or case. Comparative phraseologisms with polyptoton are always either adjectival or adverbial phrases. This type of phraseologism is characterised by phraseological fusion. The processes of primary phraseologisation are identical to those we find in fixed phrase schemes since they are based on invariant syntactic and semantic models. Through comparation and intensification of meaning, they are close to prototypical comparative phraseologisms. Their serial character and pseudohomomorphism make Middle High German comparative phraseologisms with 
polyptoton formally close to binominals. In these phraseologisms, the polyptoton shows change solely within one category, as well as syntactic distance of the reduplicated component, and it occurs in two morphological forms: as transparent polyptoton and as polyptoton with suppletion.

\section{Key words:}

polyptoton, comparative phraseologisms, Middle High German, invariance of primary phraseologisation, phraseological fusion, phraseological subclass 